\begin{tabular}{c|c|c|c|c|c|c|c|} 
DOI: http://dx.doi.org/10.21276/ap.covid19.2021.10.1.12 \\
Annals of Phytomedicine: An International Journal \\
http://www.ukaazpublications.com/publications/index.php \\
Print ISSN : 2278-9839
\end{tabular}

\title{
Potential of bryophytes in prevention and medication of COVID-19
}

\author{
Afroz Alam* \\ Department of Bioscience and Biotechnology, Banasthali Vidyapith, Banasthali-304022, Rajasthan, India
}

\section{Article Info}

Article history

Received 6 April 2021

Revised 29 May 2021

Accepted 30 May 2021

Published Online 30 June 2021

\section{Keywords}

Antiviral

Antioxidant

Bryophytes

Coronavirus

COVID-19

Viruses

\begin{abstract}
Severe acute respiratory syndrome Corona Virus-2 (SARS-CoV-2) is the latest adherent in the family Coronaviridae. It is an extremely transmissible and transmits through interaction/droplets. Early response in an infected person includes deregulations of cytokine followed by failure of the immune system. World Health Organization (WHO) stated it as worldwide wellbeing emergency regarding this pandemic. The death tally is ever increasing since the first report in Wuhan (China) in December 2019. Consequently, the scientific community of the world started the work on his remedy and suggested the obligatory precautionary actions. Though, few vaccines have been developed, yet the best option is still to take preventive measures at present in future also. Among all preventive measures, the use of herbs in our diet is the easiest and best. Many herbs with great antioxidant profiles and antiviral potential are known to us. But, usually angiosperms are the first choice to be utilized and other plants such as bryophytes have been neglected for their use as remedy to treat many diseases caused by viruses. The purpose of this review to explore and compile those bryophytes which would be the possible candidates as remedy against coronavirus as immunity boosters.
\end{abstract}

\section{Introduction}

Due to parasitic nature, viruses are obligate intracellular organisms and utilize the host cells system for its replication and spread (Casadevall, 2008; Helms et al., 2015). These infective agents are visible through Electron microscope, but images taken by transmission electron microscope only provide the morphological insight (Goldsmith and Miller, 2009). Though, morphologically these viruses have variable external structures, but they have nucleic acid and capsid called nucleocapsid as common aspect (Tellinghuisen and Kuhn, 2000). They have been classified variously, viz., classification proposed by Holmes, Baltimore and LHT system on the basis of certain parameters, such as genome, capsid and host specificity, etc. However, the system was developed in the year 1971 by David Baltimore (a Nobel laureate, 1975) for classifying viruses based on the type of genome and its replication strategy is the most recognized and accepted classification.

\subsection{Viral epidemics in past}

There are no historic hints about the beginning and progression of viruses, but the world has seen many pandemics affecting loads of individuals and mourned millions of deaths. For instance, many pandemics were reported, viz., Spanish flu (1918-1920); Ebola viral disease (2014-2016), Zika virus, Chikungunya, Dengue in many countries that resulted into millions of deaths and still active to some extent at present also. A lethal addition in this tally is SARSCoV-19 or Novel coronavirus 2019 (nCOVID-19) which appeared

Corresponding author: Dr. Afroz Alam

Associate Professor, Department of Bioscience and Biotechnology, Banasthali Vidyapith, Vanasthali-304022, Rajasthan, India

E-mail: afrozalamsafvi@gmail.com

Tel.: +91-9415596994

Copyright $(\mathcal{C} 2021$ Ukaaz Publications. All rights reserved.

Email: ukaaz@yahoo.com; Website: www.ukaazpublications.com in December, 2019 and affecting 107,415,710 of people worldwide and caused 2,351,367 deaths. However on a positive note, $79,346,885$ people have been recovered (https://www.worldometers info/coronavirus/ retrieved on 10.2.2021). On the basis of data regarding SARS-CoV-19 one thing is very much evident that level of immunity is the basic difference between life and death when anyone infected with this virus.

\subsection{SARS-CoV-19}

The name coronavirus is not new to pathology, but the earlier forms of it were only related to mild disease symptoms like common cold and cough. However, in the year 2003, a novel strain was introduced from bats to cats and then to humans. This existence caused severe acute respiratory syndrome (SARS) in humans and designated as SARS-CoV (Lu and Liu, 2012). Afterwards in 2012, another strain was passes from the camels to humans and designated as Middle East Respiratory Syndrome (MERS), and in the year 2019, a novel strain had appeared though, it was closely related to SARS-CoV-1 yet showed certain differences on the basis of its phylogenetic study, hence named as novel coronavirus SARS-CoV2 (Wu et al., 2020). It is probably transmitted from bats (Zhou et al., 2020), sea food/animal market in Wuhan, China (WHO, 2020).

So, the evolutionary trends show that the coronavirus is also evolving like other viruses and challenging the human beings to fight for their survival.

\subsection{Significance of immunity against viral attacks}

A robust resistant mechanism of human being constantly protects the body from the outbreak of countless microorganisms, but when this system weakens, it results into the start of many long-lasting diseases like COVID-19 that cannot be treated perfectly through conventional medicines. Many recent reports indicated a close interaction between Covid-19 and the immune response of an 
infected person. This activated immune response due to SARSCoV-2 in an infected individual can be alienated into two stages, the initial incubation or non-severe and the following severe stage (Shi et al., 2020).If the immune response of the infected person is sturdy, then the progression of initial stage to second stage is retarded which help in the early elimination of the virus. Accordingly, the resistance enhancing approaches are very important to provide protection at this stage. All this depends upon the all-inclusive health of the persons so that an endogenous immune response can prevent the viral activities at the initial stage (Shi et al., 2020). If the immunity of the infected individual is weak then the virus will thrive and replicate easily which results in the massive damage to the affected parts of the body, especially the tissues of lungs which become severely exaggerated and result into deadly respiratory disorders at the next stage of infection (Xu et al., 2020). It has been seen that SARS-CoV-2 affects respiration, kidney functions, liver metabolism, gastrointestinal tract, cardiac and central nervous system (Huang et al., 2020; Liu et al., 2020) subsequently many deaths have been happened due to the multiple organ failure.

\subsection{Active sites of coronavirus}

The structural investigation provided the basis for the vaccine development against COVID-19 and according to those the envelope protein (E-protein) is the minutest amid the main structural proteins having excited cytoplasmic tail and hydrophobic domain. Missing this vivacious protein expressively depresses viral load with undeveloped and ineffectual descendants (Schoeman and Fielding, 2019). Whereas, the membranous protein is responsible for the maintenance of virus capsid's shape and stabilization the overall balance of nucleocapsid by integrating the cellular golgi tool for freshly formed virions (Prajapat et al., 2020). The spike (S-glyco protein) is the distinctive ectodomain of COVID-19, which provide the all essential binding of virus particle on the specific receptors (Gordon et al, 2020) which is followed by the release of nucleocapsid (N-protein) after bulging the membrane into the cell. Like other RNA viruses, the replication and transcription of $m$-RNA genome starts from 5' end, followed by the immune hyperactivity and pulmonary devastation. Hence, the most decisive part in the pathogenicity is performed by the S-glycoprotein (Perlman and Netland, 2009). A study discovered that the binding propensity of S-glycoprotein to ACE2 in SARS-CoV-2 is about 10-to-20 times higher and with easier communication from person to person than the other known strains of this virus (Adhikari et al., 2020).

\subsection{Potential of plants against the COVID-19}

Many countries including China have explored the possibility of the utilization of Traditional Medicine system against the COVID19. Consequently, the conventional remedies and traditional medications have been found useful in the augmentation the resistance against viral attacks. As evident that the floristic wealth on this planet is a huge reservoir of medicinally important plants and they are the valuable source of numerous bioactive compounds/ secondary metabolites that act as paragon for drug findings. Since the outbreak of COVID-19, many plants have been evaluated for their potential as anti-COVID and many interesting results have been obtained (Mugisha et al., 2014; Lamorde et al., 2010; Nyamukuru et al., 2017; Khan, 2020; Mehrorta, 2020). It seems that angiosperms are the preferred plants for such studies and the second most abundant group of plants, i.e., bryophytes have been neglected.

To fill this lacuna, some of the bryophytes have been enlisted in this article that have shown antiviral potential in past.

According to many reports' bryophytes are ubiquitous remedy amid many tribes of the world and these tiny plants being used to cure several diseases, viz., to cure skin diseases, hepatic disorders, cardiovascular diseases, inflammations, microbial infection, wound, etc., since olden times (Alam, 2012; Alam and Sharma, 2015; Chandra et al., 2017). However, recent attempts on the evaluation of bryophytes for their pharmaceuticals and nutraceutical impending show that these amphibious plants have significant antioxidative, anticancerous, antiviral and antimicrobial properties.

\subsection{Bioactivity of compounds found in bryophytes}

Bryophytes create an assemblage of minor plants which form indispensable part of terrestrial flora. These plants prefer to grow in shade where the water availability is sufficient (Glime and Saxena, 1991). Ecologically, these plants always regarded as vital but for therapeutic potential some what neglect in past. However, in current scenario of herbal formulations, these amphibian plants are more and more explored for their therapeutics utilities. But still less than $10 \%$ of bryophytes have been explored for their phytochemistry (Asakawa, 2004). On the basis of attempts made on these plants, it is evident that these plants possess worthy bioactive compounds. These bioactive secondary metabolites have shown varied biological activities, viz., antimicrobial, antiviral, antitumor, cytotoxic, cardioprotective, allergy triggering, etc. (Asakawa, et al. 2014).

Liverworts are the preferred plants as they were used as cure for skin infections and liver ailments since the olden times (Friederich et al., 1999; Saroya, 2011; Gokbulut et al., 2012). Mosses are comparatively lesser explored for their therapeutic uses than the liverworts though they have more diversity than the liverworts, while hornworts yet to emerge as medicinally important plants. The secondary metabolites identified in bryophytes are usually flavonoids, terpenoids, bibenzyls, etc., along with few fatty acids and acetophenols, etc. (Asakawa et al., 2014).

Being resurrection plants, they produce various secondary metabolites to reinforce their defense to cope up with environmental stress, especially the desiccation (Xie and Lou, 2009; Dey and De, 2012; Alam et al., 2019). Since these plants are delicate and have no specific morphological and anatomical adaptation for defense therefore, they have well developed active defense at molecular and chemical level.

The antioxidant defense system delivers fortification to the cellular membranes and organelles to avoid damages due to oxidative burst under stress situations. When stressed, the reactive oxygen species (ROS) react with imperative constituents of the cell, viz., proteins and lipids of cellular membranes resulting into the disturbance in cell integrity eventually causing cell destruction. These antioxidants are, therefore, present hugely in the bryophytes, therefore these plants are well able to serve as a valuable reservoir for medicinally important phytochemicals (Aslanbaba et al., 2017). Considering this, few bryophytes were evaluated for their bioactive compounds, for instance, in the liverwort, Marchantia polymorpha, was characterized for an antioxidant enzyme peroxidase and it was reported that this peroxidase of liverwort is significantly different from any well-known peroxidase of tracheophytes (Hirata et al., 
2002). Likewise, Brachythecium velutinum (moss) and $M$. polymorpha also evaluated for the search of antioxidant enzymes and showed that the enzyme ascorbate peroxidase plays a vital role in the removal of hydrogen peroxide from the plant (Paciolla and Tommasi, 2003). The extract obtained from another liverwort, Plagiochasma appendiculatum showed noteworthy antioxidant action in preventing the lipid peroxidation by augmenting the activity of superoxide dismutase and catalase (Singh et al., 2006).

The moss, Sphagnum magellanicum showed the occurrence of various phenolic compounds like gallic, caffeic, chlorogenic, vanillic, p-coumaric, salicylic acid and 3-4 hydrozybenzoic when reversephase high-pressure liquid chromatography was done (Montenegro et al., 2009). The flavonoids extracted from the cell suspension culture of liverwort Marchantia linearis showed anticancerous potential against the cell lines of colon cancer (Krishnan and Murugan, $2013 \mathrm{a}, \mathrm{b}$ ). The antibacterial and antifungal activities of bryophytes have been evidently proved by many studies (Greeshma and Murugan, 2014; Negi et al., 2018). However, like other plant groups, the ambient environment has its instrumental effect on the quantity and quality of the secondary metabolites found in bryophytes (Vats and Alam, 2013; Thakur and Kapila, 2017). For instance, the extracts of Oxytegus tenuirostris, Rhynchostegium murale and Eurhynchium striatum were evaluated for their antioxidative properties and it was reported that the climatic factors regulate the antioxidant possessions of these mosses. It was also reported that the differences in antioxidant potential may vary within a species and amid different species (Yayintas et al., 2017). Bryophytes such as Homalothecium sericeum, Sanionia uncinata, Eurhynchium striatulum, etc., were evaluated for their free radical scavenging activity and showed appreciable results (Erturk et al., 2015).

It was also proved that isolated phytochemicals work better than the extract. Bhattarai et al. (2008) reported antioxidant of Sanionia uncinata (polar moss). An experiment performed on the extracts of Polytrichastrum alpinum revealed that the isolated phytoconstituents have two-to-seven fold augmented antioxidant action than the extract of the plant (Bhattarai et al., 2009).

The phytochemical profiling of Thuidium tamariscellum showed the occurrence of substantial terpenoids level which was responsible for its high antioxidant possessions (Mohandas and Kumaraswamy, 2018).

Studies also revealed that the total flavonoid contents of liverworts were generally higher than those of mosses, and among mosses the acrocarpous forms showed usually elevated values than the Pleurocarpous forms. This reveals that the overall content of flavonoidsis related to the light intensity because it has been observed that the species growing in habitats with low light levels contain higher flavonoids than those growing in full sun (Sabovljević, and Sabovljević, 2020).

It is also revealed that the antioxidant potential of some of the liverworts is more or less same as found in vascular plants, e.g., Plagiochasma appendiculatum showed remarkable activity of guaiacol peroxidase and catalase and Pellia endivaefolia showed excellent activity of superoxide dismutase, proline, ascorbic acid, glutathione, and total phenols when stressed (Sharma et al., 2015).
Both, antioxidant and free radical scavenging activities are of great significance for medical practitioners and dieticians. The occurrence of excessive free radicals is thought to have a crucial role in the development of many diseases (Castro and Freeman, 2001). Oxidative progressions may also decline the constancy and value of drugs and foods. These reactive oxygen species (ROS) and reactive nitrogen species (RNS) are generated during the environmental stresses and among all plants, the bryophytes have a special position because the dominant haploid (n) gametophytic phase in their life cycle. Consequently, few species have been evaluated for their tolerances against drought and floods (Robinson et al., 2002; Wasley et al., 2006) and extraordinary nitrogen concentrations (Koranda et $a l ., 2007)$. It was found that these plants are well able to adapt and answer to these stresses because of their superior and highly effectual antioxidative defense mechanism which comprises of defensive nonenzymatic as well as enzymatic strategies that competently hunt the harmful ROS and avert the damaging possessions of these nasty free radicals (Breusegem et al., 2001).

Recently, bryophytes like Claopodium crispifolium and Anomodon attenuates showed remarkable occurrence of cytotoxic and/or antitumor compounds that have been isolated and identified as an samitocin P-3. While, ohioensins and pallidisetums compounds were isolated from Polytrichum spp. (Sabovljevicì, et al., 2016).

\subsection{Antiviral activities}

Viruses are unique type of pathogens. They are nucleo-protein particles with complete dependency on the host cell machinery to survive and replicate (Webster's et al., 1998). Antiviral activity has been reported in numerous plants including bryophytes. Interestingly, there wer no evidence available regarding the infectivity of viruses to any bryophytes in past which proves that bryophytes have strict defense response in the form of their chemical constituents against the viruses. Hence, numerous bryophyte species have been identified having antiviral action against many animal and plant viruses, viz., Herpes simplex type 1, Polio type 1, Potato virus X(PVX), Zucchini Yellow Mosaic Virus (ZYMV), etc. Therefore, now the bryophytes have been recognized as a new reservoir of antiviral secondary metabolites.

Recently, few attempts have been made to find out the antiviral compounds in many bryophytes and bioflavonoids were reported to cause a controlling effect on a broad range of viral strains (Hillhouse, 2003). The secondary metabolites recognized in the bryophytes are basically terpenoids, flavonoids and bibenzyls. Among the investigated taxa, liverworts appeared as the main sources of these terpenoids, flavonoids and alkaloids (Chaudhary and Kumar, 2011).

Mosses such as Imbibryum sp., Trichostomum sp. and Barbula convoluta have been screened for antiviral properties and substantial antiviral activity was reported against Zucchini Yellow Mosaic Virus (ZYMV), the methanolic extracts of these taxa have shown about $90 \%$ inhibitory effect on the virus due to their high phenolic contents (Abdel-Shafi et al., 2017).

Phytoconstituents obtained from bryophytes, viz., Marchantins A, B and D, perrottetin F, and paleatin B exhibited anti-HIV-1 activity (Asakawa and Ludwiczuk, 2017) confirming the antiviral potential of bryophytes. 


\section{Material and Methods}

A simple method was implemented to register those plants either having the property to cure the viral infections closely related to the coronavirus or they have the possessions to offer relief from the peculiar symptoms pragmatic in the COVID-19 patients where they can trigger and reinforce the immune system. The literature search was carried out using keywords like, immune-enhancer bryophytes, medicinal bryophytes, ethnobryology, antiviral bryophytes, etc. The list of some of the bryophytes is specified (Table 1) along with their family, traditional uses, bioactive compounds and consuming methodology.

Table 1: List of some bryophytes and their reported compounds showing antioxidant activity and antiviral potential (Asakawa and Ludwiczuk, 2018; Gahtori and Chaturvedi, 2019; Sabovljević, and Sabovljevié, 2020)

\begin{tabular}{|c|c|c|}
\hline Sl. No. & Name of bryophyte & Antioxidant compounds \\
\hline 1. & Anomodon rostratus & Phenolics \\
\hline 2 . & Asterella angusta & $\begin{array}{l}\text { Asterelin A, asterelin B, 11-O- demethylmarcantin I, and dihydroptychan to } \\
\text { ladibenzofuran [bis(bibenzyl)] }\end{array}$ \\
\hline 3. & Atichum undulatum & Phenolics \\
\hline 4. & Atrichum angustatum & Phenolics \\
\hline 5. & Barbula sp. & Triglycerides \\
\hline 6. & Bryum cuspidatum & Phenolics \\
\hline 7. & Bryum moravicum & Phenolics \\
\hline 8. & Camptothecium sp. & 1-o-methylohioensin-B, 1-o-methyldihydroxyohioensin-B \\
\hline 9. & Chiloscyphus polyanthus (Plate 1: Figure 1) & Diplophyllin, sesquiterpene, lactones, diplophylloide-14, tulpinolide \\
\hline 10. & Conocephalum conicum (Plate 1: Figure 2) & Tulpinolide, Zaluzanin-C \\
\hline 11. & Dicranium sp. & Triglycerides \\
\hline 12. & Diplophyllum albicans (Plate 1: Figure 3) & Diplophylline \\
\hline 13. & Diplophyllum taxifolium & Diplophylline \\
\hline 14. & Dumortiera hirsuta (Plate 1: Figure 4) & RiccardinD [macrocyclicbis(bibenzyl)]Cell wall peroxidases and tyrosinases \\
\hline 15. & Fissidens sp. & Phenolics \\
\hline 16. & Frullania muscicola & 3-Hydroxy-42 - methoxylbibenzyl7,4-dimethyl-apigenin \\
\hline 17. & Frullania tamarisci (Plate 1: Figure 5) & Antileukemic compounds \\
\hline 18. & Haplocladium microphyllum & Phenolics \\
\hline 19. & Hyophila involuta & Phenolics \\
\hline 20. & Jungermannia subulata & Subulatin \\
\hline 21. & Lophocolea heterophylla & Subulatin \\
\hline 22. & Lunulari acruciata & Flavonoids and sesquiterpenes \\
\hline 23. & Marchantia paleacea var.diptera & Superoxide dismutase \\
\hline 24. & Marchantia palmata & neomarchantin $\mathrm{A}$, marchantins $\mathrm{A}$ and $\mathrm{B}$ \\
\hline 25 . & Marchantia polymorpha (Plate 1: Figure 6) & $\begin{array}{l}\text { Plagiochin } \mathrm{E} \text {, riccardin } \mathrm{H} \text {, marchantin E, neomarchantin } \mathrm{A} \text {, marchantins } \mathrm{A} \text { and } \\
\text { BCustunolide, } \alpha \text {-himachalene, cuparenemarchantin, } \delta \text {-elemene }\end{array}$ \\
\hline 26. & Mastigophor adiclados & Sesquiterpenoids \\
\hline 27. & Mnium sp. (Plate 2: Figure 7) & $\begin{array}{l}\text { Bicyclohumulenone, plagiochiline A, plagiochilide,plagiochilal B, } \\
\text { menthanemonoterpenoids, triterpenoidal saponins, riccardinsA and B, sacullatal }\end{array}$ \\
\hline 28. & Pallavicinia lyelli (Plate 2: Figure 8) & $\begin{array}{l}\text { Ascorbate peroxidase, } \delta \text {-elemene, calamenene, Bicyclohumulenone, plagiochiline } \\
\text { A, plagiochilide,plagiochilal B, menthanemonoterpenoids, triterpenoidal } \\
\text { saponins, riccardins A and B, sacullatal }\end{array}$ \\
\hline 29. & Philonotis fontana (Plate 2: Figure 9) & $\begin{array}{l}\text { p-hydroxycinnamic acid, Triterpenoidal saponins, p-hydroxycinnamic acid, 7- } \\
\text { 8-dihydroxycoumarin }\end{array}$ \\
\hline 30. & Plagiochasma appendiculatum & Prevent lipid peroxidation and increase antioxidant enzymes \\
\hline 31. & Plagiochila sp. (Plate 2: Figure 10) & $\begin{array}{l}\text { Bicyclohumulenone, plagiochiline A, plagiochilide,plagiochilal B, } \\
\text { menthanemonoterpenoids, triterpenoidal saponins, riccardins A and B, sacullatal }\end{array}$ \\
\hline 32 . & Plagiomnium sp. (Plate 2: Figure 11) & $\begin{array}{l}\text { Bicyclohumulenone, plagiochiline A, plagiochilide,plagiochilal B, } \\
\text { menthanemonoterpenoids, triterpenoidal saponins, riccardins A and B, sacullatal }\end{array}$ \\
\hline 33. & Platyhypnidium riparioides & Phenolics \\
\hline 34. & Polytrichastrum alpinum & Benzonaphthoxanthenones (Ohioensins F and G) \\
\hline 35. & Polytrichum formosum & Phenolics \\
\hline 36. & Porella platyphylla & Custunolide, isoeremanthin, 3 - $\beta$-hyderoxycostunolidecinnamolide \\
\hline 37. & Rhodobryum roseum & Prevents lipid peroxidation and augments antioxidants \\
\hline
\end{tabular}




\begin{tabular}{|c|l|l|}
\hline 38. & Radula complanata & Bibenzyl, 3-methoxy bibenzyl, 2-terpinine ethylbenzene \\
\hline 39. & Rhodobryum giganteum & Triterpenoidalsaponins, p-hydroxycinnamic acid,7-8-dihydroxycoumarin \\
\hline 40. & Riccardia sp. (Plate 2: Figure 12) & $\begin{array}{l}\text { Bicyclohumulenone, plagiochiline A, plagiochilide,plagiochilal B, menthanem } \\
\text { onoterpenoids,triterpenoidal saponins, riccardins A and B, sacullatal }\end{array}$ \\
\hline 41. & Sanionia uncinata & Antioxidant enzymes \\
\hline 42. & Scapania parvitexta & Subulatin \\
\hline 43. & Sphagnum magellanicum & Phenolics \\
\hline 44. & Thudium tamariscinum & Phenolics, terpenoids \\
\hline 45. & Wiesnerella denudata & Tulpinolide, costunolide, zaluzanin C \& D, 2 $\alpha$ acetoxy-zaluzanin \\
\hline
\end{tabular}
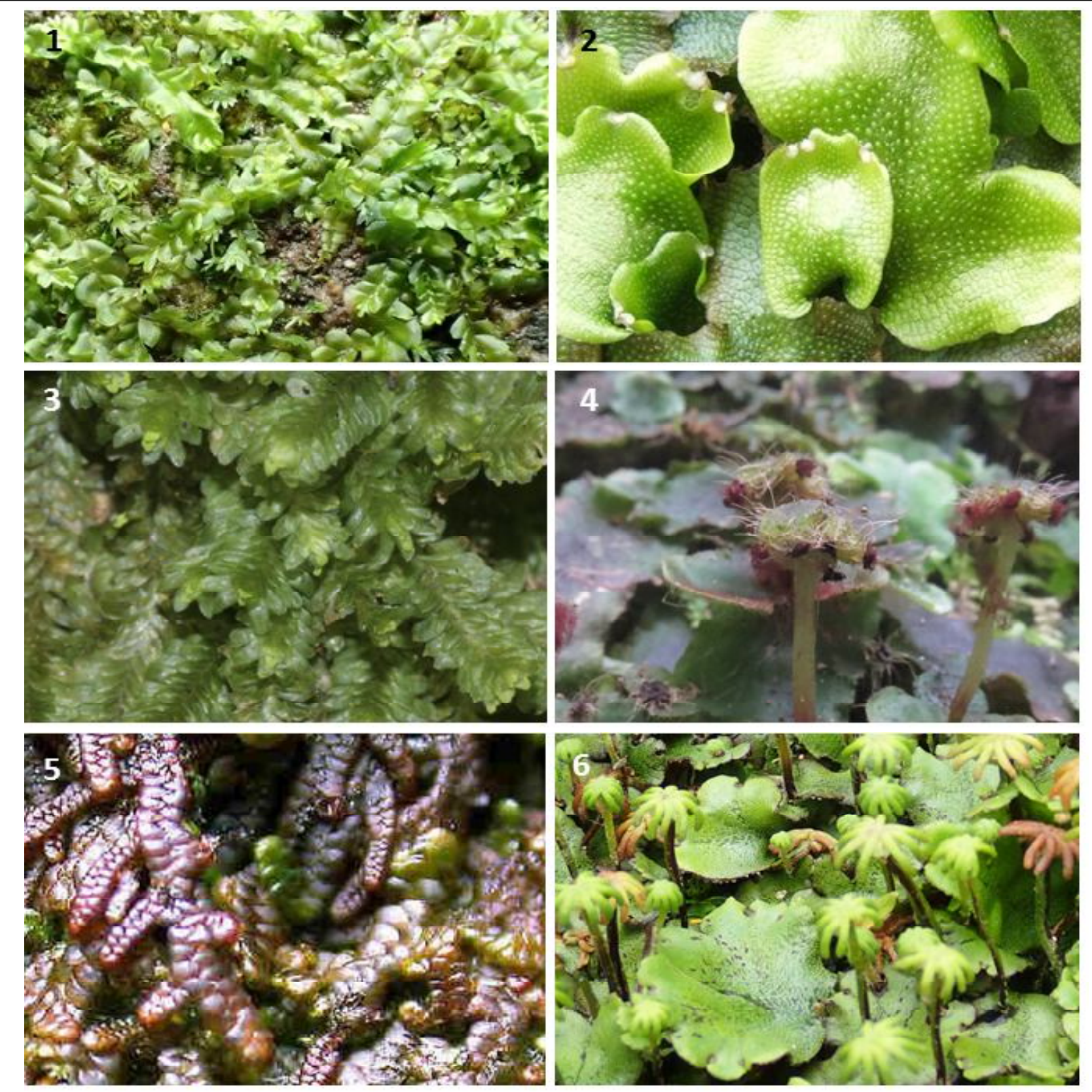

Plate 1

Figures 1-6: 1. Chiloscyphus polyanthus; 2. Conocephalum conicum; 3. Diplophyllum albicans; 4. Dumortiera hirsuta; 5. Frullania tamarisci; 6. Marchantia polymorpha. 

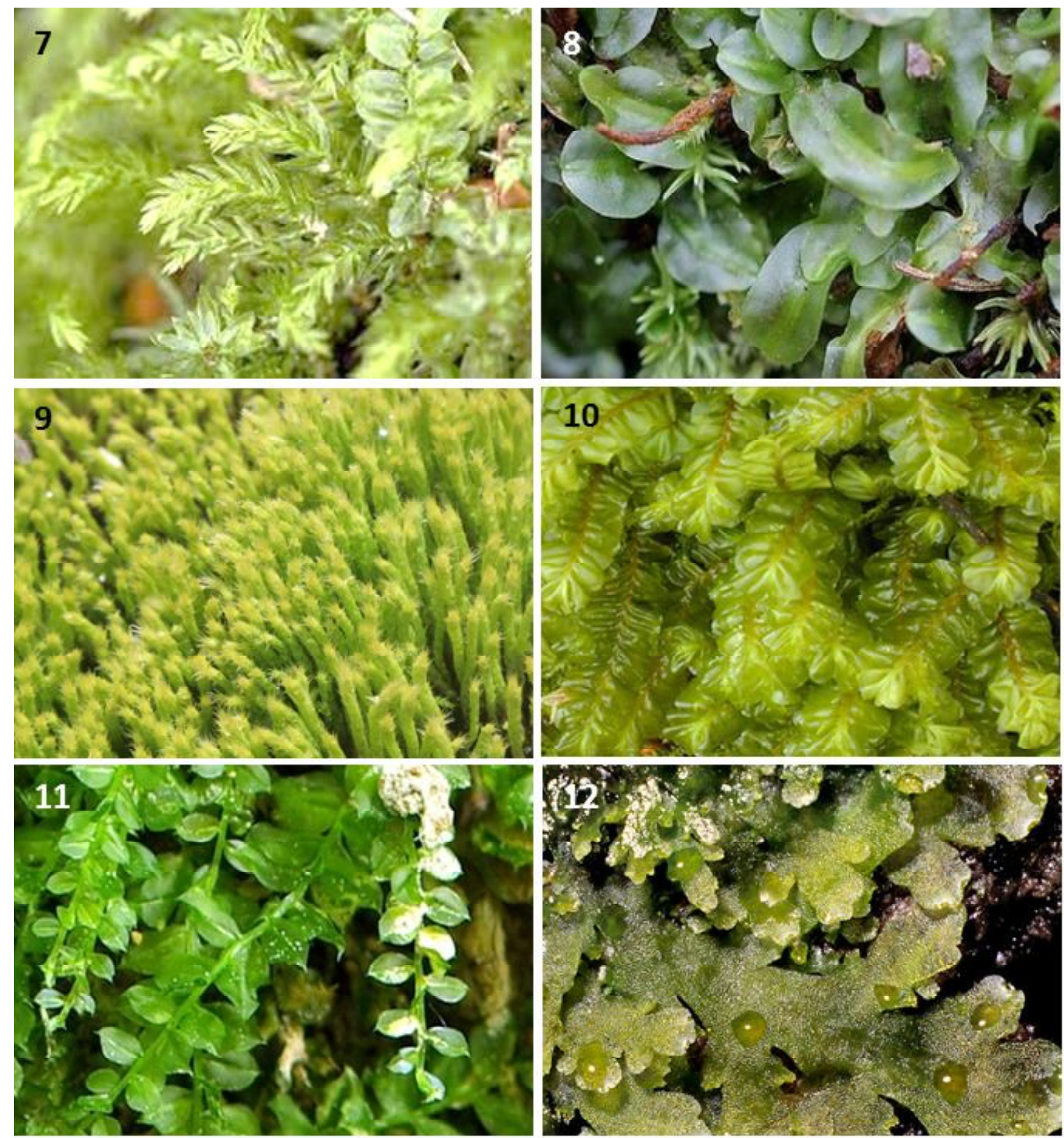

Plate 2

Figures 7-12:7. Mnium sp.; 8. Pallavicinia lyelli; 9. Philonotis fontana; 10. Plagiochila sp.; 11. Plagiomniuni sp.; 12. Riccardia sp.

\section{Conclusion}

Due to their unique thallus organization, phytoconstituents and defense responses, bryophytes have all the potential to be used in efficacious remedies to prevent and cure viral infections. These plants not only have antiviral activities but also provide natural antioxidants. Since they exist everywhere except the oceans, and can grow without any special need hence, readily available with low cost and can be used without any harmful effects on the human body. Therefore, in future they can be used as main reservoir of beneficial phytoconstituents to make natural pharmaceuticals and nutraceuticals with therapeutic utility against the viral infections. 
The antioxidants which are naturally present in these plants have great potential to boost the immunity of human beings against a range a virus, including COVID-19 by quenching the free radicalsto protect the health status of cells. Increasing occurrences of viral diseases demand the use of natural therapeutic antioxidants as consistent dietetic complements for providing improved and effective healthcare. Earlier, the focus of the scientists was on the angiosperms but now there is need to explore the bryophytes second largest group of plants for the natural healthcare systems. Since nothing is created on this planet either without the need or with no benefit to human kind therefore these plants with rich storage of useful biomolecules can also offer a more competent resource of many phytoconstituents that could be used for innovative medication.

\section{Acknowledgements}

The author is grateful to Professor Ina Aditya Shastri, Vice-Chancellor, Banasthali Vidyapith for his encouragement and support.

\section{Conflict of interest}

The author declares that there are no conflicts of interest relevant to this article.

\section{References}

Abdel-Shafi, S.; Hussein, Y.; Lashin, G. and Abdel-Monaem, Al-Shaymaa (2017) An evaluation of the antibacterial and antiviral activities of some bryophytes. Egyptian Journal of Microbiology, 52(1):63-86.

Adhikari, S.P.; Meng, S.; Wu, Y.J.; Mao, Y.P.; Ye, R.X.; Wang, Q.Z.; Sun, C.; Sylvia, S.; Rozelle, S.; Raat, H. and Zhou, H. (2020). Epidemiology, causes, clinical manifestation and diagnosis, prevention and control of coronavirus disease (COVID-19) during the early outbreak period: A scoping review. Infectious Diseases of Poverty, 9(1):1-12. doi.org/ 10.1186/s40249-020-00646-x

Alam, A. (2012). Some Indian bryophytes known for their biologically active compounds. International Journal of Applied Biology and Pharmaceutical Technology, 3(2):239-246.

Alam, A. and Sharma, V. (2015). Horticultural importance of bryophytes: A review, International Journal of Horticulture, 5(19):1-9. doi: 10.5376/ijh.2015.05.0019

Alam, A.; Dwivedi, A. and Emmanuel, I. (2019). Resurrection plants: Imperative resources in developing strategies to drought and desiccation pressure. Plant Sci. Today, 6(3):333-341.

Asakawa, Y. (2004). Chemosystematics of the hepaticae. Phytochemistry. 65:623-669.

Asakawa, Y. and Ludwiczuk, A. (2018). Chemical constituents of bryophytes: Structures and biological activity. Journal of Natural Products, 81:641-660. doi: 10.1021/acs.jnatprod.6b01046.

Asakawa, Y.; Ludwiczuk, A. and Nagashima, F. (2013). Chemical constituents of bryophytes: Bio and chemical diversity, biological activity, and chemosystematics. In: Progress in the Chemistry of Organic Natural Products. Wien: Springer; pp:796.

Aslanbaba, B.; Yilmaz, S.; TongucYayinta, O.; Ozyurt, D. and Ozyurt, B.D. (2017) Total phenol content and antioxidant activity of mosses from Yenice forest (Ida mountain). Journal of Scientific Perspectives. 1(1): $1-12$.

Bhattarai, H.D.; Paudel, B.; Lee, H.K.; Oh, H. and Yim, J.H. (2009). In vitro antioxidant capacities of two benzonaphth oxanthenones: Ohioensins F and G, isolated from the Antarctic moss Polytrichastr umalpinum. Zeitschriftfür Natur. for schung. 64(3-4):197-200.
Bhattarai, H.D.; Paudel, B.; Lee, H.S.; Lee, Y.K. and Yim, J.H. (2008). Antioxidant activity of Sanionia uncinata, a polar moss species from King George Island, Antarctica. Phytotherapy Research, 22:1635-1639.

Casadevall, A. (2008). Evolution of intracellular pathogens. Annual Review in Microbiology, 62:19-33. doi: 10.1146/annurev. micro. 61:080-706. 093305

Castro, L. and Freeman, B.A. (2001). Reactive oxygen species in human health and disease. Nutrition, 17:163-165.

Chandra, S.; Chandra, D.; Barh, A.; Pankaj, Pandey, R.K. and Sharma, I.P. (2016). Bryophytes: Hoard of remedies, an ethnomedicinal review. Journal of Traditional and Complementary Medicines, 7(1):94-98. doi:10.1016/j.jtcme.2016. 01.007

Chaudhary, B.L. and Kumar, P. (2011). Antibacterial activity and preliminary phytochemical screening of Epiphytic Moss Stereo phyllum Li gulatum Jaeg. International Journal of Pharma, and Biosciences, 2:1-4.

Dey, A. and De, J.N. (2012). Antioxidative potential of bryophytes stress tolerance and commercial perspectives: A review. Pharmacologia, 3:151-159.

Friederich, S.; Maier, U.H. and Deus-Neumann, B. (1999). Biosynthesis of cyclic bis (bibenzyls) in Marchantia polymorpha. Phytochemistry, 50:589-598.

Gahtori, D. and Chaturvedi, P. (2019). Bryophytes: A potential source of antioxidants. Intech. Open. doi.org/10.5772/intechopen.84587.

Glime, J.M. and Saxena, D.K. (1991). Uses of Bryophytes. New Delhi: Today and Tomorrow's Printers and Publishers; p:1-100.

Gokbulut, A.; Satilmis, B; Batcioglu, K.; Cetin, B. and Sarer, E. (2012). Antioxidant activity and luteolin content of Marchantia polymorpha L. Turkish Journal of Biology, 36:381-385.

Goldsmith, C.S. and Miller, S.E. (2009). Modern uses of electron microscopy for detection of viruses. Clinical Microbiology Reviews, 22(4):552-563. doi: 10.1128/CMR.00027-09

Gordon, D.E.; Jang, G.M.; Bouhaddou, M.; Xu, J.; Obernier, K.; O'Meara, M.J.; Guo, J.Z.; Swaney, D.L.; Tummino, T.A.; Huttenhain, R. and Kaake, R. (2020). A SARS-CoV-2-Human Protein-Protein Interaction Map Reveals Drug Targets and Potential Drug-Repurposing. bioRxiv. doi.org/ 10.1101/2020.03.22.002386

Greeshma, G.M. and Murugan K. (2012). Comparison of antimicrobial potentiality of the purified Terpenoids from two moss species Thuidium tamariscellum (C. muel.) Bosch. and Sande-Lac and Brachythecium buchananii (Hook.) A. Jaegr. Journal of Analytical and Pharmaceutical Research, 7(5):530-538.

Helms, J.B.; Kaloyanova, D.V.; Strating, J.R.; van Hellemond, J.J.; van der Schaar, H.M.; Tielens, A.G.; van Kuppeveld, F.J. and Brouwers, J.F. (2015). Targeting of the hydrophobic metabolome by pathogens. Traffic, 16(5), pp.439-460. doi: $10.1111 /$ tra.12280.

Hillhouse, B.J. (2003). Screening of bi flavonoid compounds and British Columbian bryophytes for antiviral activity against Potato Virus X. MS. C. Faculty of Graduate Studies, British Columbia University.

Hirata, T.; Ashida, Y. and Mori, H. (2002). A 37-kDa peroxidase secreted from liverworts in response to chemical stress. Phytochemistry, 55:197-202

Huang, C.; Wang, Y.; Li, X.; Ren, L.; Zhao, J.; Hu, Y.; Zhang, L.; Fan, G.; Xu, J.; Gu, X. and Cheng, Z. (2020). Clinical features of patients infected with 2019 novel coronavirus in Wuhan, China. The Lancet, 395(102 23 ):497-506. doi.org/10.1016/S0140-6736(20)30183-5 
Khan, A.A. (2020). Role of Unani medicine in empowering national healthcare. Ann. Phytomed., 9(2):1-5.

Koranda, M.; Kerschbaum, S.; Wanek, W.; Zechmeister, H. and Richter, A. (2007). Physiological responses of bryophytes Thuidium tamariscinum and Holocomium splendens to increased nitrogen deposition. Annals of Botany, 99:161-169.

Krishnan, R. and Murugan K. (2013b). In vitro anticancer properties of flavonoids extracted from cell suspension culture of Marchantia linearis Lehm \& Lindenb. (bryophyta) against sw 480 colon cancer cell lines. Indo American Journal of Pharmaceutical Research. 3: $1427-1437$

Krishnan, R. and Murugan, K. (2013a). Polyphenols from Marchantia polymorpha L. a bryophyta: A potential source as antioxidants. World Journal of Pharmacy and Pharmaceutical Sciences, 2:51825198

Lamorde, M.; Tabuti, J.R.; Obua, C.; Kukunda-Byobona, C.; Lanyero, H.; Byakika-Kibwika, P.; Bbosa, G.S.; Lubega, A.; Ogwal-Okeng, J.; Ryan, M. and Waako, P.J. (2010). Medicinal plants used by traditional medicine practitioners for the treatment of HIV/AIDS and related conditions in Uganda. Journal of Ethnopharmacology, 130(1):43-53. doi.org/ $10.1016 / j$.jep. 2010.04 .004

Liu, C.; Zhou, Q.; Li, Y.; Garner, L.V.; Watkins, S.P.; Carter, L.J.; Smoot, J.; Gregg, A.C.; Daniels, A.D.; Jervey, S. and Albaiu, D. (2020). Research and development on therapeutic agents and vaccines for COVID-19 and related Human Coronavirus Diseases. https://dx.doi.org/ 10.1021/acscentsci.0c00272

Lu, G. and Liu, D. (2012). SARS-like virus in the Middle East: A truly batrelated coronavirus causing human diseases. Protein and cell, 3(11):803-805. doi:10.1007/s13238-012-2811-1

Mehrotra, N. (2020). Medicinal plants, aromatic herbs and spices as potent immunity defenders: Antiviral (COVID-19) perspectives. Ann. Phytomed., 9(2):30-49.doi.org/10.21276/ap.2020.9.2.4

Mohandas, G.G. and Kumaraswamy, M. (2018). Antioxidant activities of Terpenoids from Thuidium tamariscellum (C. Muell.) Bosch. and Sande-Lac. A Moss. Pharmacognosy Journal, 10(4):645-649.

Montenegro, G.; Portaluppi, M.C.; Salas, F.A, and Diaz M.F. (2009). Biological properties of Chilean native moss Sphagnum magellanicum. Biological Research, 42(2):233-237.

Mugisha, M.K.; Asiimwe, S.; Namutebi, A.; Borg-Karlson, A.K. and Kakudidi, E.K. (2014). Ethnobotanical study of indigenous knowledge on medicinal and nutritious plants used to manage opportunistic infections associated with HIV/AIDS in western Uganda. Journal of Ethnopharmacology, 155(1):194-202. doi.org/10.1016/j.jep. 2014.05 .012

Negi, K.; Tiwari, S.D. and Chaturvedi, P. (2018). Antibacterial activity of Marchanti apapillata Raddi sub sp. Grossibarba (Steph.) Bisch against Staphylococcus aureus. Indian Journal of Traditional Knowledge, 17(4):763-769.

Nyamukuru, A.; Tabuti, J.R.; Lamorde, M.; Kato, B.; Sekagya, Y. and Aduma, P.R. (2017). Medicinal plants and traditional treatment practices used in the management of HIV/AIDS clients in Mpigi District, Uganda. Journal of Herbal Medicine, 7:51-58. doi.org/10.1016/ j.hermed.2016.10.001

Paciolla, C. and Tommasi, F. (2003). The ascorbate system in two bryophytes: Brachythecium velutinum and Marchantia polymorpha. Biologia. Plantarum, 47:387-393.

Perlman, S. and Netland, J. (2009). Coronaviruses post-SARS: Update on replication and pathogenesis. Nature Reviews Microbiology, 7(6): 439-450. doi.org/10.1038/nrmicro2147.
Prajapat, M.; Sarma, P.; Shekhar, N.; Avti, P.;Sinha, S.; Kaur, H.; Kumar, S.; Bhattacharyya, A.; Kumar, H.; Bansal, S. and Medhi, B. (2020). Drug targets for corona virus: A systematic review. Indian Journal of Pharmacology, 52(1):56-68.doi: 10.4103/ijp.IJP_115_20

Robinson, S.A.; Wasley, J.; Popp, M. and Lovelock CE. (2000). Desiccation tolerance of three moss species from continental Antarctica. Australian Journal of Plant Physiology. 27:379-388.

Sabovljević, M.S. and Sabovljević, A.D. (2020). Bryophytes. Intech open. https://doi.org/10.5772/intechopen.91420

Sabovljevicì, M.S.; Sabovljevic, A.D.; Ikram, N.K.K.; Peramuna, A.; Bae, H. and Simonsen, H.T. (2016) Bryophytes: An emerging source for herbal remedies and chemical production. Plant Genetic Resources, 1:14-15.

Saroya, A.S. (2011). Herbalism, Phytochemistry, and Ethnopharmacology. Punjab: Science Publishers, pp:286-293.

Sawicki, S.G; Sawicki, D.L. and Siddell, S.G. (2007). A contemporary view of coronavirus transcription. Journal of Virology, 81(1):20-29. doi: 10.1128/JVI.01358-06

Schoeman, D. and Fielding, B.C., (2019). Coronavirus envelope protein: Current knowledge. Virology Journal, 16(1):69-91. doi.org/ 10.1186/s12985-019-1182-0

Sharma, A.; Slatbia, S.; Gupta, D.; Handa, N.; Choudhary, S.P. and Langer. A. (2015). Antifungal and antioxidant profile of ethnomedicinally important liverworts (Pellia endivaefolia and Plagiochasma appendiculatum) used by indigenous tribes of district reasi: Northwest Himalayas. Proceedings of the National Academy of Sciences, India Section B. 85(2):571-579.

Shi, W.; Li, J.; Zhou, H. and Gao, G.F. (2017). Pathogen genomic surveillance elucidates the origins, transmission and evolution of emerging viral agents in China. Science China Life Sciences, 60(12):13171330. doi.org/10.1007/s1 1427-017-9211-0

Shi, Y.; Wang, Y.; Shao, C.; Huang, J.; Gan, J.; Huang, X.; Bucci, E.; Piacentini, M.; Ippolito, G. and Melino, G. (2020). COVID-19 infection: The perspectives on immune responses. https://doi.org/10.1038/ s41418-020-0530-3.

Singh, A.P.; Asthana, A. and Nath, V. (2000). Medicinal importance of bryophytes: A description council of scientific and Industrial Research Booklet, 2:55-62.

Singh, M.; Govindrajan, R.; Nath, V.; Rawat, A.K.S. and Mehrotra, S. (2006). Antimicrobial, wound healing and antioxidant activity of Plagiochasma appendiculatum Lehm. et Lind. Journal of Ethnopharmacology, 107:67-72.

Tellinghuisen, T.L. and Kuhn, R.J. (2000). Nucleic acid-dependent crosslinking of the nucleocapsid protein of Sindbis virus. Journal of virology, 74(9):4302-4309.doi: $10.1128 /$ JVI.74.9.43024309.2000

Thakur, S. and Kapila, S. (2017). Seasonal changes in antioxidant enzymes, polyphenol oxidase enzyme, flavonoids and phenolic content in three leafy liverworts. Lindbergia, 40:39-44.

Vats, S. and Alam, A. (2013). Antioxidant activity of Barbul ajavanica Doz. Et Molk.: A relatively unexplored bryophyte. Elixir Applied Botany, 65(3):20103-20104.

Wasley, J.; Robinson, S.A.; Lovelock, C.E. and Popp, M. (2006). Some like wet biological characteristics underpinning tolerance of extreme water stress events in Antarctic bryophytes. Functional Plant Biology, 33:443-455. 
Webster's, P.J.; Magana, V.O.; Palmer, T.N.; Shukla, J.; Tomas, R.A.; Yanai, M. and Yasunari, T. (1998). Monsoons: Processes, predictability, and the prospects for prediction. Journal of Geophysical, Res., 103(7): 14451-14510.

WHO (2020). https://www.who.int/emergencies/diseases/novelcoronavirus-2019 (Accessed on 12-Feb-2021).

Wu,A.; Peng, Y.; Huang, B.; Ding, X.; Wang, X.; Niu, P.; Meng, J.; Zhu, Z.; Zhang, Z.; Wang, J. and Sheng, J. (2020). Genome composition and divergence of the novel coronavirus (2019-nCoV) originating in China. Cell host and microbe. doi.org/10.1016/j.chom.2020.02.001

Wu, F.; Zhao, S.; Yu, B.; Chen, Y.M.; Wang, W.; Song, Z.G.; Hu, Y.; Tao, Z.W.; Tian, J.H.; Pei, Y.Y. and Yuan, M.L. (2020). A new coronavirus associated with human respiratory disease in China. Nature, 579(7798):265-269. doi.org/10.1038/s41586-020-2008-3.
Xie, C.F. and Lou, H.X. (2009). Secondary metabolites in bryophytes: An ecological aspect. 2009. Chemistry and Biodiversity, 6:303-312.

Xu,Z; Shi, L.; Wang, Y.; Zhang, J.; Huang, L.; Zhang, C.; Liu, S.; Zhao, P.; Liu, H.; Zhu, L. and Tai, Y. (2020). Pathological findings of COVID-19 associated with acute respiratory distress syndrome. The Lancet Respiratory Medicine, 8(4):420-422.doi.org/10.1016/S2213-2600(20)30076-X

Yayintas, T.O.; Sogut, O.; Konyalioglu, S.; Yilmaz, S. and Tepeli B. (2017). Antioxidant activities and chemical composition of different extracts of mosses gathered from Turkey. AgroLife Scientific Journal, 6(2):205-213.

Zhou, P.; Yang, X.L.; Wang, X.G.; Hu, B.; Zhang, L.; Zhang, W.; Si, H.R.; Zhu, Y.; Li, B.; Huang, C.L. and Chen, H.D. (2020). A pneumonia outbreak associated with a new coronavirus of probable bat origin. Nature, pp:1-4. doi.org/10.1038/s41586-020-2012-7

Afroz Alam (2021). Potential of bryophytes in prevention and medication of COVID-19. Ann. Phytomed., Volume10, Special Issue1 (COVID-19): S121-S129. http://dx.doi.org/10.21276/ap.covid19.2021.10.1.12 